\title{
ANTITUMOUR ORGANOMETALLICS. III. IN VIVO ACTIVITY OF DIPHENYLANTIMONY(III) AND DIORGANOTIN(IV) DITHIOPHOSPHORUS DERIVATIVES AGAINST P388 LEUKEMIA
}

\author{
Bernhard K. Keppler \\ Anorganisch-Chemisches Institut der Universität Heidelberg, In Neuenheimer Feld 270, D-6900 \\ Heidelberg 1, Germany \\ Cristian Silvestru and Ionel Haiduc \\ Facultatea de Chimie, Universitatea "Babes-Bolyai", RO-3400 Cluj-Napoca, Romania
}

\begin{abstract}
Diphenylantimony(III) and diorganotin(IV) derivatives of dithiophosphorus ligands, i.e. $\mathrm{Ph}_{2} \mathrm{SbS}_{2} \mathrm{PR}_{2}^{\prime}\left(\mathrm{R}^{\prime}=\mathrm{Ph}, \mathrm{OPr}-\mathrm{i}\right)$ and $\mathrm{R}_{2} \mathrm{Sn}\left(\mathrm{S}_{2} \mathrm{PR}_{2}^{\prime}\right)_{2}\left(\mathrm{R}=\mathrm{n}-\mathrm{Bu}, \mathrm{Ph}, \mathrm{R}^{\prime}=\mathrm{Ph} ; \mathrm{R}=\mathrm{Ph}, \mathrm{R}^{\prime}=\mathrm{OPr}-\mathrm{i}\right)$, have been screened against P388 leukemia in mice. All the compounds showed marginal activity towards this tumor system, some of them increasing the life span of the animals with more than $20 \%$. The best results were obtained with (di-iso-propylphosphorodithioato)diphenylantimony(III) which exhibited a T/C value of $136 \%$, at a dose of $5 \mathrm{mg} / \mathrm{kg}$, administered on days 1,2 and 3 after tumor transplantation.
\end{abstract}

\section{INTRODUCTION}

In recent years, the potential antitumor activity of organometallics, i.e. compounds containing direct metal-carbon bonds, has received an increased attention, ${ }^{1}$ since more and more derivatives of either transition and Main Group metals were found to exhibit interesting inhibitory properties on animal tumor systems. Among Main Group metal compounds, organotin(IV) derivatives occupy a top position related to their antitumor effects, with some of them being even more active than cisplatin in in vitro tests. ${ }^{2-9}$

Interest in organoantimony(III) compounds as potential antitumor agents arose in recent years when diphenylantimony(III) derivatives of dithiophosphorus ligands were reported as the first organoantimony compounds to exhibit antitumor properties in vitro and in vivo against Ehrlich ascites tumor. ${ }^{10-12}$ Comparative studies in this mouse tumor system, using diphenylantimony(III) and diphenyltin(IV) compounds containing the same dithiophosphorus ligands, pointed out that organometallic di-iso-propylphosphorodithioates were more active than diphenylphosphino- 
dithioato analogues, and the organoantimony derivatives were more active than organotins. Moreover, $\mathrm{Ph}_{2} \mathrm{SbS}_{2} \mathrm{P}(\mathrm{OPr}-\mathrm{i})_{2}$ (5 mg/kg/day, i.p. on days 1, 3 and 5$)$ produced an increase in lifespan of $83 \%$ and a cure rate of $30 \%$ in mice bearing this tumor. ${ }^{10}$

Here we report the results obtained using the same compounds as above, on P388 leukemia in mice. Additionally, a dibutyltin(IV) derivative, i.e. $\mathrm{n}-\mathrm{Bu}_{2} \mathrm{Sn}\left(\mathrm{S}_{2} \mathrm{PPh}_{2}\right)_{2}$, was included in the screening, since a lot of previous reports concerning the antitumor activity of organotins $s^{5,8,9}$ have suggested that the presence of the di-n-butyltin moiety improve the in vitro inhibitory effects against human tumor cell lines (MCF-7 and WiDr) in comparison to analogous compounds containing phenyl groups bound to tin.

\section{MATERIALS AND METHODS}

Animals. The DBA/2 (female, ca. $20 \mathrm{~g}$ ) and BDF 1 mice (female, 20-22 g) were provided by Zentralinstitut für Versuchstierkunde, Hannover (FRG) and kept under conventional conditions: 3 mice per Macrolon III cage, tap water and Altromin pellets ad libitum. Room temperature was at about $20^{\circ} \mathrm{C}$; room air kept circulating 20 times/hour; a light/dark rhythm was maintained over 12 hours.

Compounds. The organometallic compounds used as antitumor agents were prepared and purified as described earlier: bis(diphenylphosphinodithioato)diphenyltin(IV), $\mathrm{Ph}_{2} \mathrm{Sn}_{(}\left(\mathrm{S}_{2} \mathrm{PPh}_{2}\right)_{2}$ (compound 1 - KP 1215), ${ }^{13}$ bis(di-iso-propylphosphorodithioato)diphenyltin(IV), $\mathrm{Ph}_{2} \mathrm{Sn}\left[\mathrm{S}_{2} \mathrm{P}(\mathrm{OPr}-\mathrm{i})_{2}\right]_{2}$ (compound 2 - KP 1216), ${ }^{14}$ bis(diphenylphosphinodithioato)di-n-butyl$\operatorname{tin}(\mathrm{IV}), \mathrm{n}-\mathrm{Bu}_{2} \mathrm{Sn}\left(\mathrm{S}_{2} \mathrm{PPh}_{2}\right)_{2}$ (compound $3-\mathrm{KP}$ 1217), ${ }^{13}$ (di-iso-propylphosphorodithioato)diphenylantimony(III), $\mathrm{Ph}_{2} \mathrm{SbS}_{2} \mathrm{P}(\mathrm{OPr}-\mathrm{i})_{2}$ (compound 4 - KP 1218), ${ }^{15}$ and (diphenylphosphinodithioato)diphenylantimony(III), $\mathrm{Ph}_{2} \mathrm{SbS}_{2} \mathrm{PPh}_{2}$ (compound 5 - KP 1219). ${ }^{16}$

In vivo experiments. P388 leukemia cells were implanted intraperitoneally into DBA/2 mice for propagation 7 days before the experiment. The tumor cells were taken from these animals at the begining of the experiment immediatelly after cervical dislocation. Then we implanted $10^{6}$ of these cells, suspended in $0.2 \mathrm{ml}$ of physiological saline, intraperitoneally into female BDF 1 mice, body weight 20-22 g, for testing. Then the mice were arbitrarily divided into groups of each time six animals, with one group serving as control. Therapy started 24 hours post transplantationem (= day 1 ) with a single dose of the respective organometallic compounds, applied intraperitoneally as suspension in physiological saline. As emulsifiers we used cremophorEL/propylenglycole. Therapy was repeated on days 2 and 3.

\section{RESULTS AND DISCUSSION}

The organometallic compounds used in this screening differ not only in the nature of the metal, organic groups bound to the metal atom, presence of aryl or alkoxy groups attached to 
phosphorus, but also by the molecular structure in solid state (Figure 1). Thus, all three diorganotin(IV) derivatives are monomeric compounds. However, for diphenyl- and di-n-butyltin(IV) diphenylphosphinodithioates 1 and 3 , the infrared and Mössbauer data suggest an angular orientation of the $\mathrm{Sn}-\mathrm{C}$ bonds and anisobidentate coordination of the dithioligands, ${ }^{13}$ while for the di-iso-propylphosphorodithioato analogue 2 , the C-Sn-C angle is $180^{\circ}$ and the ligands are isobidentate as determined by X-ray diffractometry. ${ }^{14}$ For both diphenylantimony(III) derivatives 4 and 5 , the solid state structures were also investigated by the $X$-ray method. The phosphorodithioato 4 has a polymeric chain structure developed through weak $\mathrm{Sb}$...S secondary bonds, the ligand acting effectivelly as a triconnective moiety. ${ }^{15}$ The dithioligand has also a triconnective behavior in the phosphinodithioato analogue 5 , but leading in this case to distinct dimeric units ${ }^{16}$ (Figure 1).

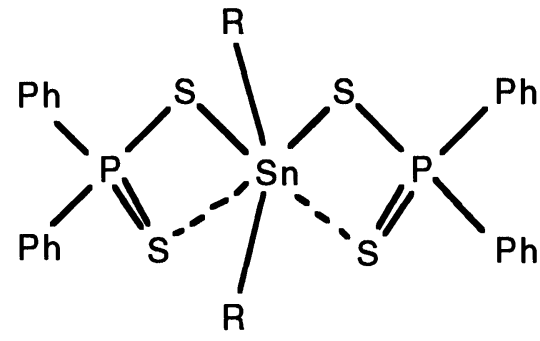

1, $R=P h$

3, $\mathrm{R}=\mathrm{Bu}-\mathrm{n}$

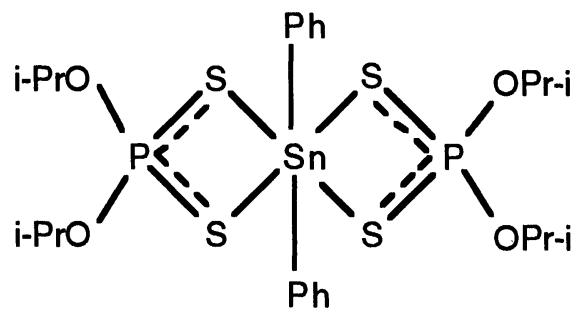

2

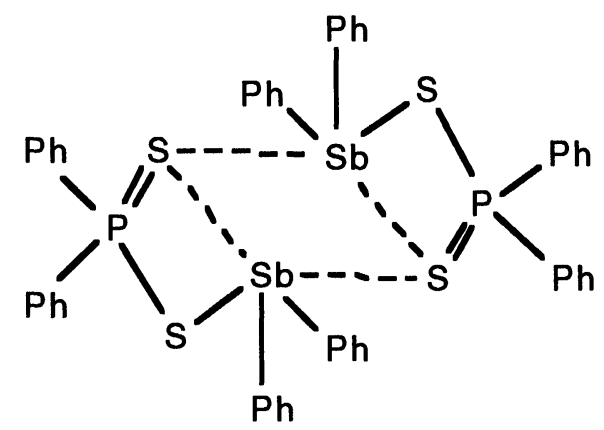

5

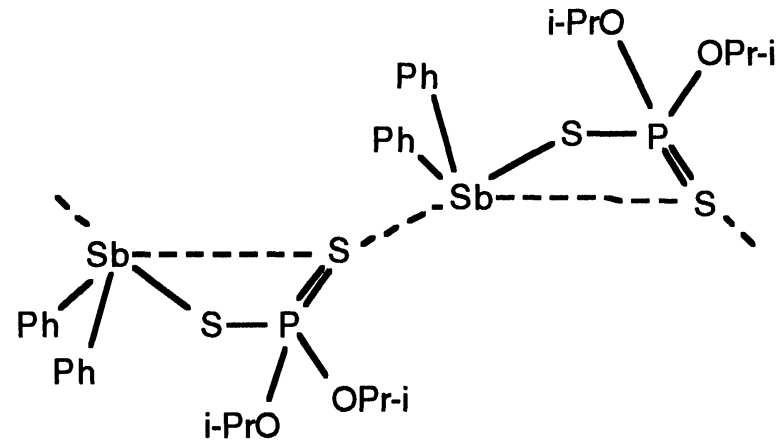

4

Figure 1. Molecular structures of organoantimony(III) and organotin(IV) compounds tested as antitumor agents against P388 leukemia in mice.

The antitumor effects of the above organometallic compounds against P388 leukemia in mice are listed in Table 1. All the diorganotin(IV) derivatives 1, 2 and 3 , and the (diphenylphosphinodithioato)diphenylantimony(III) 5 , exhibited only marginal activity (T/C ca. 120\%). Although 
the T/C value of $127 \%$ obtained for compound 3 was the best in the series of organotins, the presence of the di-n-butyltin(IV) moiety did not spectacularly improve the antitumor properties.

As in the previous experiments on Ehrlich ascites tumor, ${ }^{10-12}$ the most active compound was (di-iso-propylphosphorodithioato)diphenylantimony(III). It exhibited a T/C of $136 \%$ at a dose of $5 \mathrm{mg} / \mathrm{kg}$, administered on days 1,2 and 3 , after tumor transplantation. However, when increasing the dose, the toxic effect of this compound seems to be stronger, since a decreased T/C value (i.e. $118 \%$ ) was obtained.

Table 1. Test results of organoantimony(III) and organotin(IV) compounds against P388 leukemia in mice.

\begin{tabular}{|c|c|c|c|c|}
\hline \multirow[t]{2}{*}{ Compound } & \multirow[t]{2}{*}{ Day of death } & \multicolumn{2}{|c|}{ Dose $^{a}$} & \multirow{2}{*}{$\begin{array}{l}T / C^{b} \\
(\%)\end{array}$} \\
\hline & & $\mathrm{mmol} / \mathrm{kg}$ & $\mathrm{mg} / \mathrm{kg}$ & \\
\hline Control & $11,11,11$ & - & - & 100 \\
\hline Cisplatin & $\begin{array}{l}20,21,27 \\
27,33,33\end{array}$ & 0.013 & 4 & 245 \\
\hline 1 & $\begin{array}{r}3,13,13 \\
14,16,16\end{array}$ & 0.006 & 5 & 123 \\
\hline 2 & $\begin{array}{l}12,12,13 \\
13,13,13\end{array}$ & 0.007 & 5 & 118 \\
\hline 3 & $\begin{array}{l}11,12,14 \\
14,15,16\end{array}$ & 0.0065 & 5 & 127 \\
\hline \multirow[t]{2}{*}{4} & $\begin{array}{l}12,12,15 \\
15,15,26\end{array}$ & 0.01 & 5 & 136 \\
\hline & $\begin{array}{l}12,13,13 \\
13,14,14\end{array}$ & 0.02 & 10 & 118 \\
\hline \multirow[t]{2}{*}{5} & $\begin{array}{l}12,12,13 \\
13,13,14\end{array}$ & 0.0095 & 5 & 118 \\
\hline & $\begin{array}{l}11,12,13 \\
14,16,16\end{array}$ & 0.019 & 10 & 123 \\
\hline
\end{tabular}

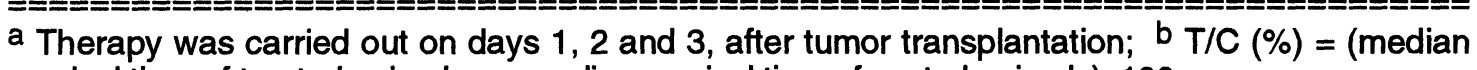
survival time of treated animals vs. median survival time of control animals)x100.

\section{REFERENCES}

1. I. Haiduc and C. Silvestru, Organometallics in Cancer Chemotherapy, CRC Press, Boca Raton, Florida; Vol.I., 1989; Vol.II., 1990.

2. M. Gielen (Ed.), Tin-Based Antitumor Drugs, NATO ASI Series: Cell Biology, Vol.37, Springer Verlag, Berlin, 1990. 
3. M. Bouâlam, R. Willem, M. Biesemans, B. Mahieu and M. Gielen, Heteroatom Chem., 1991, 2, 447.

4. M. Bouâlam, R. Willem, M. Biesemans and M. Gielen, Appl.Organomet.Chem., 1991, 5, 497.

5. S.W. Ng, V.C. Kumar Das, M. Gielen and E.R.T. Tiekink, Appl.Organomet.Chem., 1992, 6, 19.

6. M. Gielen, J. Meunier-Piret, M. Biesemans, R. Willem and A. El Khloufi, Appl.Organomet. Chem., 1992, 6, 59.

7. M. Gielen, P. Lelieveld, D. de Vos, H. Pan, R. Willem, M. Biesemans and H.H. Fiebig, Inorg.Chim.Acta, 1992, 196, 115.

8. M. Gielen, A. El Khloufi, M. Biesemans and R. Willem, Polyhedron, 1992, 15, 1861.

9. M. Gielen and R. Willem, Anticancer Res., 1992, 12, 257.

10. C. Silvestru, C. Socaciu, A. Bara and I. Haiduc, Anticancer Res., 1990, 10, 803.

11. A. Bara, C. Socaciu, C. Silvestru and I. Haiduc, Anticancer Res., 1991, 11, 1651.

12. C. Socaciu, A. Bara, C. Silvestru and I. Haiduc, In Vivo, 1991, 5, 425.

13. C. Silvestru, F. Ilies, I. Haiduc, M. Gielen and J.J. Zuckerman, J.Organomet.Chem., 1987, $330,315$.

14. H. Lefferts, K.C. Molloy, J.J. Zuckerman, I. Haiduc, M. Curtui, C. Guta and D. Ruse, Inorg. Chem., 1980,19, 2861.

15. C. Silvestru, M. Curtui, I. Haiduc, M.J. Begley and D.B. Sowerby, J.Organomet.Chem., 1992, 426, 49.

16. C. Silvestru, L. Silaghi-Dumitrescu, I. Haiduc, M.J. Begley, M. Nunn and D.B. Sowerby, J.Chem.Soc., Dalton Trans., 1986, 1031.

Received: August 18, 1993 - Accepted: September 9, 1993 